\title{
Spiders associated with the meadow and tree canopies of orchards respond differently to habitat fragmentation
}

\author{
John D. Herrmann • Debra Bailey • \\ Gabriela Hofer • Felix Herzog • \\ Martin H. Schmidt-Entling
}

Received: 17 August 2009/Accepted: 28 July 2010/Published online: 15 August 2010

(C) Springer Science+Business Media B.V. 2010

\begin{abstract}
The response of animal communities to habitat quality and fragmentation may vary depending on microhabitat associations of species. For example, sensitivity of species to woody habitat fragmentation should increase with their degree of association with woody plants. We investigated effects of local and landscape factors on spider communities in different microhabitats within Swiss apple orchards. We expected a stronger negative effect of woody habitat fragmentation on spiders inhabiting tree canopies compared to spiders living in the meadow. The 30 orchards that we sampled varied in woody habitat amount and isolation at landscape and patch scales. Local factors included management intensity and plant diversity. Spiders associated with meadow were affected by plant diversity, but not by fragmentation. In contrast, spiders associated with canopies responded to isolation from other woody habitats. Surprisingly, we found both positive and negative effects of habitat isolation on local abundance. This indicates that differences in dispersal and/or biotic interactions shape the specific response to habitat isolation. The relative importance of local and landscape factors was in
\end{abstract}

J. D. Herrmann $(\bowtie) \cdot$ M. H. Schmidt-Entling Institute of Ecology and Evolution, University of Bern, Baltzerstrasse 6, 3012 Bern, Switzerland

e-mail: john-herrmann@gmx.de

D. Bailey · G. Hofer · F. Herzog

Research Station Agroscope Reckenholz-Tänikon ART, Reckenholzstrasse 191, 8046 Zürich, Switzerland accordance with the microhabitat of the spiders. Thus, considering microhabitat associations can be important for identifying processes that would be overlooked if sampling were pooled for the whole habitat.

Keywords Microhabitat · Woodland fragmentation - Habitat loss · Habitat isolation . Farmland biodiversity $\cdot$ Araneae

\section{Introduction}

Distribution and abundance of arthropods depend on properties of the local habitat as well as the wider landscape (Samu et al. 1999; Tscharntke et al. 2005). Arthropod assemblages can be affected by a variety of local factors such as plant species composition (Waloff 1980; Beals 2006) or land-use intensity (Olszak et al. 1992a; Dennis et al. 2001). Due to their high mobility, arthropods also can be influenced by the landscape at scales up to several kilometres (Tscharntke and Brandl 2004).

Habitats can be subdivided into different microhabitats with distinct assemblages of organisms (Whitehouse et al. 2002). Depending on the focal organisms, such a microhabitat could be related to the vertical layering of soil (Stanton 1988) or vegetation (Renjifo 1999). The multiple factors that influence local assemblages may have varying effects on species occupying different microhabitats of a given habitat type (Driscoll and Weir 2005). For example, the 
vulnerability of plant species to habitat fragmentation varies with microhabitat preference (Turner et al. 1996). Also, birds occupying different strata of the Columbian forests showed different levels of vulnerability to extinction following fragmentation (Kattan et al. 1994; Renjifo 1999). Discovering influences of microhabitat preferences on fragmentation sensitivity would aid conservation planning, especially for arthropods with their high species diversity. This approach can be of particular importance because information on life-history traits that might otherwise predict fragmentation effects is sparse for many arthropod groups (Ewers and Didham 2006).

Here, we studied effects of local and landscape factors on spider communities in different microhabitats within apple orchards. We chose spiders as study organisms because they are abundant, diverse and have well-defined habitat preferences. Furthermore, dispersal abilities of spiders range from small-scale, cursorial dispersal to large-scale ballooning, which results in variable responses to habitat fragmentation (Bonte et al. 2004; Schmidt et al. 2008). To distinguish between effects of habitat loss and isolation (Fahrig 2003) of spider communities, we performed a GISbased selection of study sites that kept variation in isolation from other woody habitats as independent as possible from percentage of woody habitats in the surrounding landscapes (Bailey et al. 2010). We expected that sensitivity to woody habitat fragmentation would increase with the degree of association of spiders with woody plants (Ewers and Didham 2006); spiders occupying orchard meadows would be less sensitive than spiders living in tree canopies. To assess the relative importance of fragmentation effects, local properties of the orchards also were taken into account. The specific study hypotheses were: (1) spiders form distinct assemblages within different microhabitats of the orchard; (2) these groups respond differently to local factors and fragmentation; and (3) importance of woody habitat fragmentation for species increases with the degree of their association with woody plants.

\section{Methods}

Study sites

We selected thirty traditional orchards in northeastern Switzerland for this study, which were the same as in Bailey et al. (2010). The sites were located at altitudes between 420 and $650 \mathrm{~m}$ above sea level and distributed over an area of about $440 \mathrm{~km}^{2}$ in the cantons of Thurgau and St. Gallen. These cantons hold the highest density of orchard plantations in Switzerland (Rinker 2004). The selected orchards were $0.4-2.9$ ha in size and dominated by tallgrowing mature apple trees (Malus domesticus) with a mean tree age of 61 years. All orchards were under reduced insecticide management, and three of them were certified organic. The landscape around the focal orchards consisted mainly of permanent grassland, arable fields, mixed deciduous forest, and other traditional orchards, though the composition varied. We selected the 30 sites to vary in (1) isolation from the nearest woody habitat $(0-245 \mathrm{~m})$, and (2) percentage of woody habitat in the surrounding landscape $(3.1-25.5 \%)$ within a $500 \mathrm{~m}$ radius. We kept these two aspects of habitat fragmentation as independent as possible by performing a GIS-based pre-selection of study sites. However, although the sites were selected from more than 12,000 potential study sites, a moderate correlation between isolation and percentage of woody habitats could not be avoided ( $r=$ -0.52 ). As structural similarity between habitats is one of the most important determinants of population exchange in spiders (Samu et al. 1999), we classified scrub and hedgerows, other extensively used orchards, single trees and tree lines as suitable habitat for orchard spiders (Olszak et al. 1992b; Miliczky and Horton 2005). For woodlands, we ranked only the woodland edges ( $5 \mathrm{~m}$ buffer) as suitable habitat as their spider fauna is similar to that of traditional orchards (Sackett et al. 2008).

\section{Local and landscape scale factors}

We calculated the landscape parameters within a $500 \mathrm{~m}$ radius around the focal orchards using a geographical information system (ArcGIS, Environmental Systems Research Institute, Inc., Redlands, USA) and FRAGSTATS (McGarigal et al. 2002). The maps were generated using ortho images and the landscape model Vector25 (swisstopo, Wabern) and then updated in the field. We used a $500 \mathrm{~m}$ radius as it is a suitable scale for studying spiders (e.g., Schmidt et al. 2008). We calculated four parameters for each buffer: patch area, patch isolation, landscape area, and landscape isolation (Table 1). 
Table 1 Environmental factors at local and landscape scales used as explanatory variables in the analyses of apple orchard biodiversity

\begin{tabular}{|c|c|c|c|}
\hline Scale & Factor & Abbreviation & Description \\
\hline \multirow[t]{2}{*}{ Local } & Plant diversity & $\mathrm{PD}$ & Number of plant species within four $10 \mathrm{~m}^{2}$ sample areas \\
\hline & Management & MA & $\begin{array}{l}\text { First principal component on management aspects including amount of } \\
\text { deadwood; number of sulphur, insecticide, fungicide, copper, liquid } \\
\text { manure, solid manure, and mineral fertilizer applications per year; } \\
\text { frequency of pruning; the presence of grazing and the number of mowing } \\
\text { events per year }\end{array}$ \\
\hline \multirow[t]{4}{*}{ Landscape } & Patch area & PA & Area of the focal orchard $\left(\mathrm{m}^{2}\right)$ \\
\hline & Patch isolation & PI & $\begin{array}{l}\text { Euclidean distance (m) from focal orchard to the nearest neighbouring } \\
\text { woody habitat (edge-to-edge distance) }\end{array}$ \\
\hline & Landscape area & LA & $\%$ area of all woody habitats within a $500 \mathrm{~m}$ buffer \\
\hline & $\begin{array}{l}\text { Landscape } \\
\text { isolation }\end{array}$ & LI & $\begin{array}{l}\text { Average Euclidean distance }(\mathrm{m}) \text { from each habitat patch to the next nearest } \\
\text { habitat patch within } 500 \mathrm{~m} \text { landscape buffer (edge-to-edge distances) }\end{array}$ \\
\hline
\end{tabular}

We performed a botanical survey from mid-May to mid-June to measure the richness of plant species in the meadow (Table 1). Plants were recorded in each orchard within four circles of $10 \mathrm{~m}^{2}$ : two circles around different apple tree trunks, and two circles outside of the canopy-shaded area. Additionally, we interviewed the farmers about the history and management of their orchards including these factors: organic farming, tree pruning, manuring, pesticide use, grazing, mowing, haying, and deadwood in trees.

\section{Sampling design}

We conducted four samplings between April and October 2007. We sampled four trees per orchard, two of which were located at the edge and two in the second row from the edge, respectively. All sampled trees were of similar height (4-6 m) and had trunk circumferences between 80 and $100 \mathrm{~cm}$. The same trees were used for all four sampling events. Beating tray sampling was used to sample spiders from the canopies. We used a $0.25 \mathrm{~m}^{2}$ textile funnel with a jar attached to its lower end. The funnel was held beneath a branch, which was struck sharply three times with a foam wrapped stick (IOBC 1978). The collected spiders were transferred to $70 \%$ ethanol. Four similar sized branches at heights of 1.5-2.5 m were sampled at each of the four trees, giving a total sample area of $4 \mathrm{~m}^{2}$ per orchard per date.

We colleted spiders from the meadow using suction sampling (Macleod et al. 1994; Dinter and Poehling 1995). Suction sampling was performed by using a handheld blower powered by a two-stroke engine (Stihl SH 85). A tapering gauze bag (mesh $<0.5 \mathrm{~mm}$ ) was inserted into the standard nozzle (11 $\mathrm{cm}$ diameter) to intercept arthropods. At each of the four selected trees, we took two samples of $0.25 \mathrm{~m}^{2}$ taken under the tree canopy ( $1 \mathrm{~m}$ from tree trunk), and two samples of $0.25 \mathrm{~m}^{2}$ taken $2 \mathrm{~m}$ outside of the canopy-shaded area. Thus, we sampled $2 \mathrm{~m}^{2}$ of shaded meadow plus $2 \mathrm{~m}^{2}$ of open meadow per orchard per date. Each sample took about $30 \mathrm{~s}$. The suction samples were transferred to plastic bags and frozen at $-20^{\circ} \mathrm{C}$ until sorting. Spiders were then transferred to $70 \%$ ethanol.

We counted all collected spiders and identified adult spiders to species level (Roberts 1996; Nentwig et al. 2003) following nomenclature by Platnick (2008). One exception was the Philodromus aureolus group (including $P$. aureolus, $P$. predatus, and possibly others) that could not be identified to species level. The immature individuals of the species Anyphaena accentuata were identified by using non-reproductive characters.

\section{Statistical analysis}

We combined the local factors that were mainly evaluated with the aid of the interviews into principal components analysis (PCA) using Canoco for Windows version 4.5 (ter Braak and Šmilauer 2002). We used the first axis of the analysis to represent management intensity (Table $1 ; \lambda=0.20$ ). Thereby, an increase in management intensity represented a higher frequency of mowing (up to six times per 
year), and copper and sulphur applications. In contrary, orchards with low management intensity had a higher amount of deadwood and were mown less often. All but the three most commonly mown orchards were grazed (see Bailey et al. 2010 for details).

We tested the differences in the abundance of spider species between microhabitats with linear mixed-effects models. Species that occurred in less than five orchards were excluded, which left 32 species for analysis. Abundance data were $\log _{10}$ $(x+1)$ transformed to improve normality of residuals. To test for differences between canopies and meadows, the microhabitat (canopy versus meadow) was used as a fixed factor and the orchard number was used as a random factor.

To determine the relative importance of local and landscape factors on species assemblages, we performed constrained ordinations in which canopy and meadow spiders were analysed separately. As gradient length of preliminary detrended correspondence analyses did not exceed three SD, we used a redundancy analysis (hereafter 'RDA'). In both datasets, we performed a forward selection with local and landscape factors to select those that significantly explained variation in spider communities (based on Monte-Carlo permutation tests with 9,999 permutations). The calculations were performed using Canoco 4.5 (ter Braak and Šmilauer 2002). We used General linear models to analyze the influences of local and landscape factors on the 33 spider species. Landscape factors were $\log _{10}(x+1)$ transformed to normalise residuals.

We tested the differences in species life-history traits between spiders from the two microhabitats with linear models. Body length values were taken from Entling et al. 2010 and $\log _{10}(x+1)$ transformed. Habitat preference was expressed as the niche position on a gradient from open to woody habitats after Entling et al. (2007). The values are scaled from 0 to 1 , whereby 0 represents the strongest preference for open habitats, and 1 the strongest preference for closed forest that can be found among Central European spiders. Habitat specialization was expressed as the niche width on the same gradient (Entling et al. 2007). An index of aerial dispersal was calculated by dividing the number of individuals of each spider species found in aerial samples in western Switzerland (Blandenier 2009) by the commonness of the species in Switzerland (Maurer and Hänggi 1990). In cases where species were determined only to genus level in the aerial samples, we divided the individual numbers of the genus by the sum of the commonness values of all species within the respective genus. All models were calculated using the $\mathrm{R}$ software (version 2.3.1; R Development Core Team 2006), and mixed effect models using the nlme package (Pinheiro et al. 2008).

\section{Results}

As expected, spider assemblages in the canopy and in the meadow were strongly differentiated. The canopy was dominated by the families Philodromidae (43\%), Araneidae (19\%) and Theridiidae (17\%), whereas the meadow was dominated by Linyphiidae (74\%), Tetragnathidae $(15 \%)$ and Lycosidae $(8 \%)$. Of the 32 tested species, 29 had higher abundances in one of the two microhabitats (Table 2) and were used for further analyses. Thirteen species could be classified as canopy spiders and another 16 species could be classified as meadow spiders.

Analysis of the four selected species traits showed that the species within the canopy and meadow groups did not differ overall in dispersal ability or body length (Table 3 ). However, canopy spiders had a stronger preference for woody habitats and were more specialized than were meadow spiders.

Canopy spider communities were affected by patch isolation $(P=0.013)$, which explained $8.7 \%$ of the variation in species composition (Fig. 1A). Of the four species that responded significantly to patch isolation, only Anyphaena accentuata and Paidiscura pallens showed the expected decrease in local abundance with increasing isolation (Table 4). In contrast, Araniella opistographa and Clubiona brevipes had higher densities in isolated orchards than in connected orchards. Additionally, both Philodromus aureolus and Salticus zebraneus responded to landscape isolation and were more abundant in landscapes with widely spaced habitat patches (Table 4). At the patch scale, $C$. brevipes and Tetragnatha montana decreased in abundance with increasing area, whereas only Dictyna arundinacea had higher numbers in larger orchards. In contrast, D. arundinacea and Theridion pinastri were negatively affected by higher woody habitat amount at landscape scale. C. brevipes 
Table 2 Microhabitat associations (canopy and meadow) for spiders within apple orchards

\begin{tabular}{|c|c|c|c|c|c|c|c|}
\hline \multirow[t]{2}{*}{ Spider species } & \multirow[t]{2}{*}{ Abbreviation } & \multicolumn{2}{|c|}{ Canopy } & \multicolumn{2}{|c|}{ Meadow } & \multirow[b]{2}{*}{$t$-value } & \multirow[b]{2}{*}{$P$-value } \\
\hline & & Mean & $\mathrm{SE}$ & Mean & SE & & \\
\hline \multicolumn{8}{|l|}{ Canopy spiders } \\
\hline Anyphaena accentuata & Anyacc & 5.2 & 0.9 & 0.1 & 0.1 & 9.9 & $<0.001$ \\
\hline Araniella opisthographa & Araopi & 1.3 & 0.2 & 0.0 & 0.2 & 5.8 & $<0.001$ \\
\hline Clubiona brevipes & Clubre & 0.5 & 0.2 & 0.0 & 0.2 & 2.7 & 0.011 \\
\hline Dictyna arundinacea & Dicaru & 0.3 & 0.1 & 0.0 & 0.1 & 2.6 & 0.016 \\
\hline Gibbaranea gibbosa & Gibgib & 0.3 & 0.1 & 0.0 & 0.1 & 2.8 & 0.009 \\
\hline Hypomma cornutum & Hypcor & 1.0 & 0.3 & 0.1 & 0.3 & 2.8 & 0.008 \\
\hline Lathys humilis & Lathum & 1.0 & 0.2 & 0.3 & 0.2 & 3.2 & 0.003 \\
\hline Paidiscura pallens & Paipal & 0.3 & 0.2 & 0.0 & 0.2 & 2.2 & 0.039 \\
\hline Philodromus albidus & Phialb & 0.2 & 0.1 & 0.0 & 0.1 & 2.5 & 0.017 \\
\hline Philodromus aureolus group & Phiaur & 1.7 & 0.3 & 0.0 & 0.3 & 6.1 & $<0.001$ \\
\hline Salticus zebraneus & Salzeb & 0.3 & 0.1 & 0.0 & 0.1 & 2.8 & 0.009 \\
\hline Tetragnatha montana & Tetmon & 0.4 & 0.1 & 0.0 & 0.1 & 2.8 & 0.009 \\
\hline Theridion pinastri & Thepin & 1.3 & 0.2 & 0.0 & 0.2 & 4.9 & $<0.001$ \\
\hline \multicolumn{8}{|l|}{ Meadow spiders } \\
\hline Araeoncus humilis & Arahum & 0.2 & 0.1 & 1.7 & 0.1 & -4.1 & $<0.001$ \\
\hline Centromerita bicolor & Cenbic & 0.0 & 0.0 & 0.7 & $\mathbf{0 . 0}$ & -2.4 & 0.022 \\
\hline Dicymbium nigrum & Dicnig & 0.0 & 0.0 & 9.7 & $\mathbf{0 . 0}$ & -6.1 & $<0.001$ \\
\hline Diplocephalus latifrons & Diplat & 0.0 & 0.0 & 1.7 & 0.0 & -2.1 & 0.041 \\
\hline Diplostyla concolor & Dipcon & 0.0 & 0.0 & 8.4 & $\mathbf{0 . 0}$ & -4.6 & $<0.001$ \\
\hline Erigone atra & Eriatr & 0.0 & 0.0 & 2.8 & $\mathbf{0 . 0}$ & -4.9 & $<0.001$ \\
\hline Erigone dentipalpis & Eriden & 0.2 & 0.1 & 16.5 & 0.1 & -6.2 & $<0.001$ \\
\hline Meioneta rurestris & Meirur & 0.1 & 0.1 & 2.3 & 0.1 & -4.1 & $<0.001$ \\
\hline Oedothorax apicatus & Oedapi & 0.0 & 0.0 & 0.8 & 0.0 & -2.5 & 0.02 \\
\hline Oedothorax fuscus & Oedfus & 0.3 & 0.1 & 20.2 & 0.1 & -6.5 & $<0.001$ \\
\hline Pachygnatha degeeri & Pacdeg & 0.0 & 0.0 & 10.0 & $\mathbf{0 . 0}$ & -7.1 & $<0.001$ \\
\hline Pardosa agrestis & Paragr & 0.1 & 0.0 & 0.1 & $\mathbf{0 . 0}$ & -2.2 & 0.032 \\
\hline Pardosa palustris & Parpal & 0.0 & 0.0 & 1.4 & $\mathbf{0 . 0}$ & -4.9 & $<0.001$ \\
\hline Robertus neglectus & Robneg & 0.0 & 0.0 & 0.3 & $\mathbf{0 . 0}$ & -2.6 & 0.016 \\
\hline Tenuiphantes tenuis & Tenten & 0.0 & 0.0 & 2.2 & $\mathbf{0 . 0}$ & -4.5 & $<0.001$ \\
\hline Tiso vagans & Tisvag & 0.0 & 0.0 & 4.7 & $\mathbf{0 . 0}$ & -6.7 & $<0.001$ \\
\hline \multicolumn{8}{|l|}{ No preference } \\
\hline Micrargus subaequalis & Micsub & 0.0 & 0.0 & 1.8 & 0.0 & -1.6 & 0.125 \\
\hline Panamomops sulcifrons & Pansul & 0.0 & 0.0 & 0.8 & 0.0 & -1.6 & 0.121 \\
\hline Porrhomma microphthalmum & Pormic & 0.1 & 0.0 & 0.1 & 0.0 & -0.9 & 0.402 \\
\hline
\end{tabular}

Mean number of individuals are presented with bold values denoting significantly higher densities in one of the two microhabitats

was the only species affected by plants in the meadow and decreased with increasing plant diversity. Abundance of $T$. pinastri was related negatively to management intensity.

Spiders inhabiting the orchard meadow were affected by the number of plant species $(P=0.001)$, which explained $11.9 \%$ of the species composition (Fig. 1B). Araeoncus humilis, Centromerita bicolor, and Pardosa agrestis were positively affected by increasing plant diversity, whereas Oedothorax fuscus had lower abundances in meadows with many plant species (Table 4). Most meadow spiders had higher 
Table 3 Test for differences in species traits for spiders in the canopy and meadow groups

\begin{tabular}{lccllllll}
\hline & \multicolumn{3}{l}{ Canopy } & & \multicolumn{3}{l}{ Meadow } \\
\cline { 2 - 3 } \cline { 7 - 8 } Species trait & Mean & SE & & Mean & SE & $t$-value & $P$ value \\
\hline Dispersal & 16.8 & 2.1 & & 16.1 & 2.7 & 0.2 & 0.856 \\
Body length & 1.1 & 0.1 & & 1.1 & 0.1 & 0.5 & 0.603 \\
$\begin{array}{l}\text { Habitat } \\
\text { preference }\end{array}$ & 0.53 & 0.05 & & 0.27 & 0.03 & 5.3 & $<\mathbf{0 . 0 0 1}$ \\
$\begin{array}{c}\text { Habitat } \\
\text { specialization }\end{array}$ & 0.11 & 0.02 & & 0.18 & 0.01 & -2.9 & $\mathbf{0 . 0 0 8}$ \\
\hline
\end{tabular}

Bold values are significant

densities in smaller orchards, and this pattern was significant for Erigone atra and Meioneta rurestris. Furthermore, Diplostyla concolor and Tenuiphantes tenuis decreased in numbers with increasing amount of woody habitat in the landscape. The meadow spider O. apicatus was more abundant in landscapes with better connected woody habitats. Two spiders, E. dentipalpis and T. tenuis, responded negatively to increasing management intensity (Table 4).

\section{Discussion}

Spiders in apple orchards showed a clear preference for microhabitats, and responses to local factors and habitat fragmentation depended on microhabitat associations of groups. Plant diversity was the most influential local factor on meadow spiders, whereas patch isolation was most influential on canopy spiders. Canopy spiders had a closer relation to woody habitats and were more specialized than meadow spiders (Table 3). In contrast, the orchard meadows were dominated by generalist open land species, mostly of the family Linyphiidae. Notably, many species classified as meadow spiders in the current study are commonly found in open farmland (Samu and Szinetár 2002; Schmidt and Tscharntke 2005). This phenomenon resembles the loss of specialist species from habitat fragments and immigration of habitat generalists from matrix habitats (e.g. As 1999; Summerville 2004).

A caveat regarding microhabitat classification relates to the use of different sampling methods for canopies and the meadow. Suction samples tend to be more effective than beat tray samples for sampling

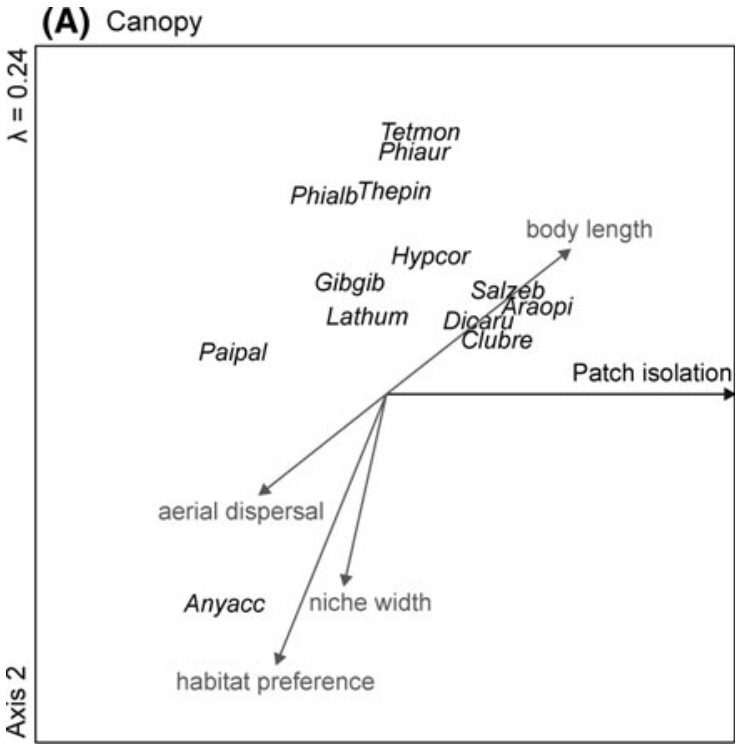

Axis 1

$\lambda=0.09$

(B) Meadow

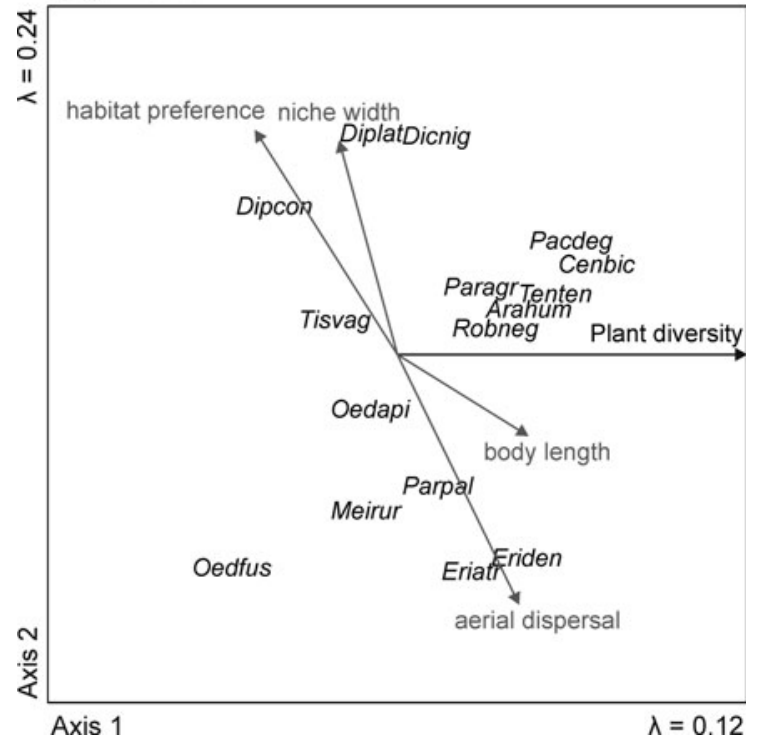

Fig. 1 Response of (A) canopy spiders and (B) meadow spiders to environmental factors based on redundancy analysis (RDA). The species traits in grey were added as passive environmental variables. For abbreviations see Table 2

spiders in low vegetation (Kharboutli and Allen 2000), thus different communities could have been collected using these two methods. However, as suction and beating tray sampling were the most useful methods for each particular microhabitat (Samu et al. 1997; Bolzern and Hänggi 2005), we assumed that bias was not considerable due to the differing methods. 
Table 4 Significant effects of local and landscape factors on spiders typical of the tree canopy and meadow microhabitats

\begin{tabular}{|c|c|c|c|c|c|c|c|}
\hline & Species & PA & PI & LA & LI & MA & PD \\
\hline \multirow[t]{13}{*}{ Canopy spiders } & Anyacc & & $-2.9 * *$ & & & & \\
\hline & Araopi & & $2.5 *$ & & & & \\
\hline & Clubre & $-2.4 *$ & $2.6 *$ & & & & $-3.1 * *$ \\
\hline & Dicaru & $2.2 *$ & & $-3.6 * *$ & & & \\
\hline & Gibgib & & & & & & \\
\hline & Hypcor & & & & & & \\
\hline & Lathum & & & & & & \\
\hline & Paipal & & $-2.1 *$ & & & & \\
\hline & Phialb & & & & & & \\
\hline & Phiaur & & & & $2.2 *$ & & \\
\hline & Salzeb & & & & $2.2 *$ & & \\
\hline & Tetmon & $-2.4 *$ & & & & & \\
\hline & Thepin & & & $-2.6 *$ & & $-2.1 *$ & \\
\hline \multirow[t]{16}{*}{ Meadow spiders } & Arahum & & & & & & $2.1 *$ \\
\hline & Cenbic & & & & & & $3.8 * * *$ \\
\hline & Dicnig & & & & & & \\
\hline & Diplat & & & & & & \\
\hline & Dipcon & & & $-2.4 *$ & & & \\
\hline & Eriatr & & & & & & \\
\hline & Eriden & $-2.1 *$ & & & & $-2.1 *$ & \\
\hline & Meirur & $-2.5 *$ & & & & & \\
\hline & Oedapi & & & & $-2.2 *$ & & \\
\hline & Oedfus & & & & & & $-3.3 * *$ \\
\hline & Pacdeg & & & & & & \\
\hline & Paragr & & & & & & $2.8 * *$ \\
\hline & Parpal & & & & & & \\
\hline & Robneg & & & & & & \\
\hline & Tenten & & & $-2.8 * *$ & & $-2.4 *$ & \\
\hline & Tisvag & & & & & & \\
\hline
\end{tabular}

For abbreviations see Tables 1 and 2. Numbers indicate $t$-values of the General Linear Model

Levels of statistical significance: * $P<0.05$; ** $P<0.01$; *** $P<0.001$

Furthermore, our classification is supported by other studies (Roberts 1996; Nentwig et al. 2003) in which most of our investigated canopy species are classified as highly specific to woody plants.

In contrast to hypotheses widely supported in landscape studies, there was a balance between positive and negative effects of patch isolation on canopy spiders (Fig. 1A, Table 4). This outcome suggests that reduced immigration into isolated orchards (as formulated in metapopulation theory; e.g., Hanski 1999) was of minor importance for canopy spiders. The positive effects of patch isolation may be caused by higher food availability, lower predation pressure in isolated orchards, or both. Indeed, densities of insectivorous canopy-dwelling birds (mostly Parus sp.) were lower in isolated orchards compared to orchards connected with other woody habitats (Bailey et al. 2010). In addition, wasps (Hymenoptera: Pomplilidae and Crabronidae) that provide their brood cells with canopy-dwelling spiders have significantly lower densities in isolated compared to connected orchards (Schüepp et al. 2010 and J. D. Herrmann, unpublished data). Both of these patterns suggest that habitat isolation reduced mostly high-order predators, creating 
a form of enemy-free space for spiders. These biologically mediated effects seemed to outweigh the reduced immigration probability of most canopy spiders into isolated orchards. The potential role of higher food availability in isolated orchards (e.g., through food from the agricultural landscape matrix) requires further investigation. Positive effects of habitat isolation on invertebrates might also result from the different microclimate of isolated compared to connected habitat fragments (Grimbacher et al. 2006). Indeed, abundances of A. opistographa and C. brevipes increased with increasing light intensity derived from indicator values of the ground vegetation (J.D. Herrmann, unpublished data). However, light intensity varied independently of patch isolation in our orchards ( $n=30, r=-0.02, P=0.90$ ), and densities of $A$. opistographa and $C$. brevipes did not correlate with any other microclimatic variable (temperature and humidity, also derived from the ground vegetation). Thus, we regard positive effects of habitat isolation on spider densities due to microclimatic differences as unlikely.

Woody habitat loss at patch and landscape scales affected four of the open land generalist species found in the meadow, whereas habitat isolation was of minor importance for spiders inhabiting the meadow (Table 4). All significant effects of woody habitat amount on spider abundance were negative. As these generalists are known to immigrate into smaller woodland patches (Cook et al. 2002; De Bakker et al. 2002) and switch between habitat types, interactions between woody and open habitats may affect spider population dynamics on a landscape scale (Topping 1999). The observed dominance of open land species points to an extensive spillover from arable land and grassland into orchard meadows (Rand et al. 2006). Gallé (2008) even concluded that woodland patches with a high edge-to-area ratio could be considered as complete edge and therefore be penetrated by open land species.

The most important local factor for spiders in the meadow was plant diversity. The mainly positive influence of plant diversity (Fig. 1A, Table 4) on these spider assemblages is in accordance with previous studies (Gibson et al. 1992; Downie et al. 1995). Positive effects of plant diversity on spiders may be due to higher structural diversity (Bell et al. 2001). Furthermore, some spider species are enhanced by plant species composition if their prey has particular plant requirements (Waloff 1980; Beals 2006). In addition, some spider species inhabiting the canopies hibernate in the herbaceous layer (Wyss et al. 1995). In this way, the ground cover in orchards may have directly influenced canopy spiders (Wyss et al. 1995; Bogya and Markó 1999). The mainly positive responses to plant species richness indicate that conservation of plants in orchard meadows will also favor spiders. Increasing management intensity had negative effects on some canopy and meadow spiders (Table 4), but was not significant at the community level. This absence of a community-wide effect of management intensity may have resulted from our pre-selection of orchards with generally low management intensity.

\section{Conclusion}

Microhabitat differentiation of orchard spider assemblages was strong, and spiders in the different microhabitats showed variable responses to local factors and habitat fragmentation. Differing responses were independent from species traits like body length and dispersal ability, but responses were affected by habitat preference and habitat specialization. Thus, considering differentiation between microhabitats can be important for identifying processes that would be overlooked if species were pooled across the whole habitat.

Acknowledgments We thank P. Eberhardt for help in the field, K. Stämpfli for generating field maps, R. G. H. Bunce for his theoretical input, and W. Nentwig for his support. We are grateful to all farmers who allowed conducting this study in their orchards. The manuscript benefitted greatly from suggestions by Robert L. Schooley and two anonymous reviewers. This study was supported by the Swiss National Science foundation under grant number 3100A0-114058 to F. Herzog and M. H. Schmidt-Entling.

\section{References}

As S (1999) Invasion of matrix species in small habitat patches. Conserv Ecol 3:1. http://www.ecologyandsociety.org/vol3/ iss1/art1/. Accessed Jan 2009

Bailey D, Schmidt-Entling MH, Eberhart P, Herrmann JD, Hofer G, Kormann U, Herzog F (2010) Effects of habitat amount and isolation on biodiversity in fragmented traditional orchards. J Appl Ecol. doi:10.1111/j.1365-2664. 2010.01858.x 
Beals ML (2006) Understanding community structure: a datadriven multivariate approach. Oecologia 150:484-495

Bell JR, Wheater CP, Cullen WR (2001) The implications of grassland and heathland management for the conservation of spider communities: a review. J Zool 255:377-387

Blandenier G (2009) Ballooning of spiders (Araneae) in Switzerland: general results from an eleven-year survey. Bull Br Arachnol Soc 14(7):308-316

Bogya S, Markó V (1999) Effect of pest management systems on ground-dwelling spider assemblages in an apple orchard in Hungary. Agr Ecosyst Environ 73:7-18

Bolzern A, Hänggi A (2005) Spinnenfänge (Arachnida, Araneae) auf subalpinen Fichten der Alp Flix (GR, Schweiz)ein Methodenvergleich. Mitt Schweiz Entomol Ges 78:125-141

Bonte D, Baert L, Lens L, Maelfait J-P (2004) Effects of aerial dispersal, habitat specialisation, and landscape structure on spider distribution across fragmented grey dunes. Ecography 27:343-349

Cook WM, Lane KT, Foster BL, Holt RD (2002) Island theory, matrix effects and species richness patterns in habitat fragments. Ecol Let 5:619-623

De Bakker D, Maelfaitn J-P, Desender K, Hendrickx F, DeVos B (2002) Regional variation in spider diversity of flemish forest stands. In: Toft S, Scharff N (eds) European arachnology 2000. Aarhus University, Aarhus, Denmark, pp 177-182

Dennis P, Young MR, Bentley C (2001) The effects of varied grazing management on epigeal spiders, harvestmen and pseudoscorpions of Nardus stricta grassland in upland Scotland. Agr Ecosyst Environ 86:39-57

Dinter A, Poehling HM (1995) Side-effects of insecticides on two erigonid spider species. Entomol Exp Appl 74: $151-163$

Downie IS, Butterfield JEL, Coulson JC (1995) Habitat preferences of sub-montane spiders in northern England. Ecography 18:51-61

Driscoll DA, Weir T (2005) Beetle responses to habitat fragmentation depend on ecological traits, habitat condition, and remnant size. Conserv Biol 19:182-194

Entling W, Schmidt MH, Bacher S, Brandl R, Nentwig W (2007) Niche properties of Central European spiders: shading, moisture and the evolution of the habitat niche. Global Ecol Biogeogr 16:440-448

Entling W, Schmidt-Entling MH, Bacher S, Brandl R, Nentwig W (2010) Body size-climate relationships of European spiders. J Biogeogr 37:477-485

Ewers RM, Didham RK (2006) Confounding factors in the detection of species responses to habitat fragmentation. Biol Rev 81:117-142

Fahrig L (2003) Effects of habitat fragmentation on biodiversity. Annu Rev Eco Syst 34:487-515

Gallé R (2008) The effect of naturally fragmented landscape on spider assemblages. North-Western J Zool 4:61-71

Gibson CWD, Hambler C, Brown VK (1992) Changes in spider (Araneae) assemblages in relation to succession and grazing management. J Appl Ecol 29:132-142

Grimbacher PS, Catterall CP, Kitching RL (2006) Beetle species' responses suggest that microclimate mediates fragmentation effects in tropical Australian rainforest. Austral Ecol 31:458-470
Hanski I (1999) Metapopulation ecology. Oxford University Press, Oxford

Kattan GH, Alvarez-Lopez H, Giraldo M (1994) Forest fragmentation and bird extinctions: San Antonio eighty years later. Conserv Biol 8:138-146

Kharboutli MS, Allen CT (2000) Comparison of sampling techniques for tarnished plant bug and predaceous arthropods. In: Proceedings of the 2000 Cotton Research Meeting, pp 167-171

Macleod A, Wratten SD, Hardwood RWJ (1994) The efficiency of a new lightweight suction sampler for sampling aphids and their predators in arable land. Ann Appl Biol 124:11-17

Maurer R, Hänggi A (1990) Katalog der schweizerischen Spinnen. Centre Suisse de Cartographie de la Faune, Neuchâtel, Suisse

McGarigal K, Cushman SA, Neel MC, Ene E (2002) FRAGSTATS: spatial pattern analysis program for categorical maps. Computer software program produced by the authors at the University of Massachusetts, Amherst. http://www.umass.edu/landeco/research/fragstats/ fragstats.html. Accessed Aug 2009

Miliczky ER, Horton DR (2005) Densities of beneficial arthropods within pear and apple orchards affected by distance from adjacent native habitat and association of natural enemies with extra-orchard host plants. Biol Control 33:249-259

Nentwig W, Hänggi A, Kropf C, Blick T (2003) Spinnen Mitteleuropas/Central European Spiders. An internet identification key. http://www.araneae.unibe.ch. Accessed Aug 2009

Olszak RW, Luczak J, Zajac RZ (1992a) Species composition and numbers of spider communities occurring on different species of shrubs. Ekologia Polska 40:287-313

Olszak RW, Luczak J, Niemczky E, Zajac RZ (1992b) The spider community associated with apple trees under different pressure of pesticides. Ekologia Polska 40:265-286

Pinheiro J, Douglas B, DebRoy S, Sarkar D, R Core team (2008) NLME: linear and nonlinear mixed effects models. $\mathrm{R}$ package version 3. pp s1-89

Platnick NI (2008) The world spider catalog, version 9.0. American Museum of Natural History. http://research.am nh.org/entomology/spiders/catalog/index.html. Accessed Jan 2009

Rand TA, Tylianakis JM, Tscharntke T (2006) Spillover edge effects: the dispersal of agriculturally subsidized insect natural enemies into adjacent natural habitats. Ecol Lett 9:603-614

Renjifo LM (1999) Composition changes in a subandean avifauna after long-term forest fragmentation. Conserv Biol 13:1124-1139

Rinker K (2004) Canton Thurgau (TG). (Zürich \& Northeastern Switzerland). Switzerland Adventure Guide

Roberts MJ (1996) Collins field guide. Spiders of Britain and northern Europe

Sackett TE, Buddle CM, Vincent C (2008) Comparisons of the composition of foliage-dwelling spider assemblages in apple orchards and adjacent deciduous forest. Can Entomol 140:338-347

Samu F, Szinetár C (2002) On the nature of agrobiont spiders. J Arachnol 30:389-402 
Samu F, Nemeth J, Kiss B (1997) Assessment of the efficiency of a hand-held suction device for sampling spiders: improved density estimation or oversampling? Ann Appl Biol 130:371-378

Samu F, Sunderland KD, Szinetar C (1999) Scale-dependent dispersal and distribution patterns of spiders in agricultural systems: a review. J Arachnol 27:325-332

Schmidt MH, Tscharntke T (2005) The role of perennial habitats for Central European farmland spiders. Agr Ecosyst Environ 105:235-242

Schmidt MH, Thies C, Nentwig W, Tscharntke T (2008) Contrasting responses of arable spiders to the landscape matrix at different spatial scales. J Biogeogr 35:157-166

Schüepp C, Herrmann JD, Herzog F, Schmidt-Entling MH (2010) Differential effects of habitat isolation and landscape composition on wasps, bees, and their enemies. Oecologia. doi:10.1007/s00442-010-1746-6

Stanton NL (1988) The underground in grasslands. Annu Rev Ecol Syst 19:573-589

Summerville KS (2004) Do smaller forest fragments contain a greater abundance of Lepidoptera crop and forage consumers? Environ Entomol 33:234-241

ter Braak CJF, Šmilauer P (2002) CANOCO reference manual and user's guide to Canoco for windows: software for canonical community ordination, version 4.5. Microcomputer Power, Ithaca, NY

Topping CJ (1999) An individual-based model for dispersive spiders in agroecosystems: simulations of the effects of landscape stucture. J Arachnol 27:378-386

Tscharntke T, Brandl R (2004) Plant-insect interactions in fragmented landscapes. Ann Rev Entomol 49:405-430

Tscharntke T, Klein AM, Kruess A, Steffan-Dewenter I, Thies C (2005) Landscape perspectives on agricultural intensification and biodiversity-ecosystem service management. Ecol Lett 8:857-874

Turner IM, Chua KS, Ong JSY, Soong BC, Tan HTW (1996) A century of plant species loss from an isolated fragment of lowland tropical rain forest. Conserv Biol 10:1229-1244

Waloff N (1980) Studies on grassland leafhopper (Auchenorhyncha: Homoptera) and their natural enemies. Adv Ecol Res 11:81-215

Whitehouse MEA, Shochat E, Shachak M, Lubin Y (2002) The influence of scale and patchiness on spider diversity in an arid environment. Ecography 25:395-404

Wyss E, Niggli U, Nentwig W (1995) The impact of spiders on aphid populations in a strip-managed apple orchard. J Appl Entomol 119:473-478 